\title{
A new concept for hard rock aquifers survey and management: individual blocks approach
}

\author{
${ }^{* 1} \mathrm{KT}$. Yao, ${ }^{2} \mathrm{O}$. Fouché, ${ }^{1} \mathrm{M}-\mathrm{S}$. Oga, ${ }^{3} \mathrm{G}$. Ferriere and ${ }^{1} \mathrm{D}$. Baka \\ 'Université Cocody, LSTEE, 22 BP 582, Abidjan, Côte d'Ivoire. \\ ${ }^{2}$ Université Paris Est, LEESU, École des Ponts ParisTech, 6-8 avenue Blaise Pascal, Cité Descartes, \\ Champs-sur-Marne, 77455 Marne-la-vallée cedex 2, France. \\ ${ }^{3}$ CNAM, Chaire de matériaux, 2 rue Conté, 75003 Paris, France. \\ ${ }^{*}$ Corresponding Author: +22505000107/ koffiyao@ymail.com
}

\begin{abstract}
The survey area is located south-west of Côte d'Ivoire in Precambrian metamorphic and plutonic zone. To highlight the network of kilometer-scale fractures in the base, remote sensing techniques were used. The map of lineaments obtained after processing of satellite images discretized the study area into blocks aquifers. This is a new approach in the study of the circulation of groundwater in hard-rock which allows going from a regional view to a local scale. The blocks were delimited by opened or clogged fractures that can have a conducting or watertight function, even a capacitor role. Statistical and fractal analyses of the geometric block parameters showed that those ones revealed the connectivity degree and the importance of the small fractures (fissured layer) in groundwater flow in hard-rock. This report is confirmed by high yields observed in the small blocks.
\end{abstract}

Key words: block, Hard-rock, aquifer, hydrodynamism, fissured zone, yield

\section{INTRODUCTION}

Africa, like much of South America, Australia, and India, is a continent that relies extensively on groundwater resources for water consumption (Courtois et al., 2010). This prior concern about the groundwater for drinking water supply is due to the shortage and above all the bad quality of the surface water caused by the unsuitable agricultural and domestic pollution management (Jourda et al., 2005). However, the groundwater exploitation remains difficult particularly in hard-rock areas which are heterogeneous and complex media. It is notably the case in Cote d'Ivoire where $97.5 \%$ of its geological substratum is made up by plutonic and metamorphic rocks (Tagini, 1971, Yacé, 2002).

To understand the mode of occurrence and the groundwater fluxes mass in this type of media, some studies have been conducted in several regions of Côte d'Ivoire by Engalenc (1979), Savané et al. (1997), Biémi et al. (1997), Lasm and Razack (2001), Kouamé et al. (2005), Jourda et al. (2006), Youan Ta et al. (2008). The discontinued aquifers mapping resulting from these studies were uniquely based on a concept of lineament. According to Hobbs (1904), the lineament refers to a significant line of the landscape, having a straight or curved layout, caused by joints or faults that reveal the architecture of the geological substratum. Also, the lineament was defined by Woodruff et al. (1982) as a figure that (1) is perceived in an image of a solid planetary body, (2) is linear and continuous, (3) has definable end points and lateral boundaries, (4) has a relatively high length-to-width ratio and hence a discernible azimuth, and (5) is shown or presumed to be correlated to stratigraphic or geologic structure. 
Am. J. Sci. Ind. Res., 2012, 3(4): 208-220

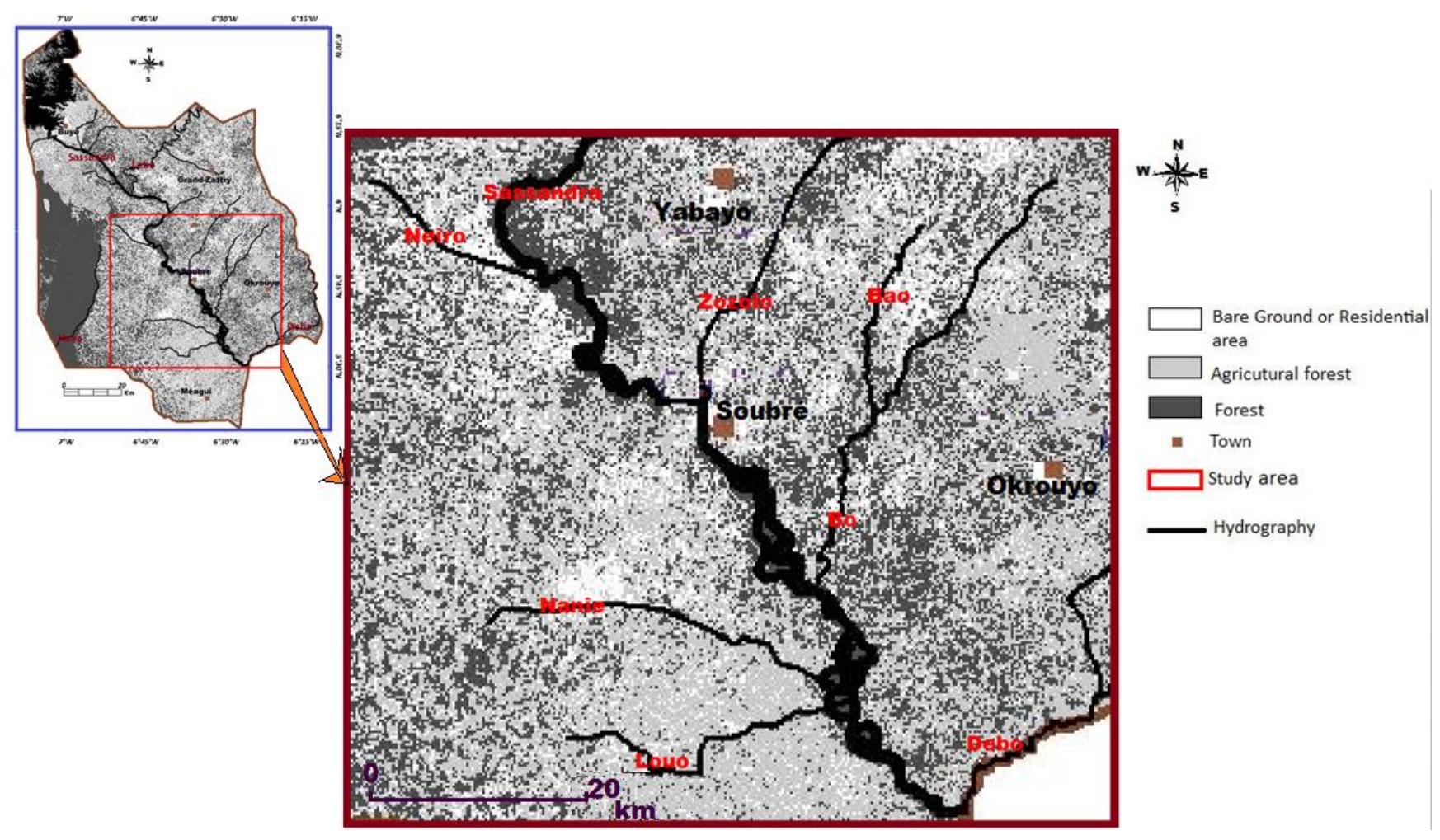

Fig 1. Basemap of department of Soubre

Since the studies of Lattman and Parizek (1964), Mabee et al. (1994); Magowe and Carr (1999), the interpretation of lineament for hydrogeological purpose is based on the idea that intensity of fracture is significantly compared to the substratum creates probably conducting fault zones of groundwater. In severals works, lineament, assimilated to a fracture is considered as an object necessarily more conductive than the rocky volume that contains it. This view of the regional percolating network is to put into perspective because it is not based on tangible proofs. Moreover, the presence of superficial formation (saprolite) and the role of fissured horizon are totally neglected, that is not realistic. In addition the studies of Taylor and Howard (2000) and Dewandel et al. (2006) assume that hydrodynamic properties are inherited from in situ weathering of these rocks.

Mabee et al. (2002) mentioned that the lineaments are not systematically related to appreciable contributions of water along a tunnel, not even $50 \%$ of them. Some zones detected as water providers have not been foreseen on the lineament map. However, we believe in agreement with Faillat (1986), Stauffer (1987), Odling (1992) and Berkowitz
(1995), that connectivity and density of factures is an important control factor for water flow in the hard-rock media. The fractures form some connected networks where only most extended can be some paths in a given volume.

In this paper, we considered that fractures divide the bedrock aquifers into communicating or isolated blocks of varying sizes.

This approach is inspired by authors who studied the probability of block size distribution in local geomechanical modeling like the evaluation of a massive effort to host the deep disposal of radioactive waste (Fouché, 1999) or the risk of rockfall in the mountains (Lempereur-Mot, 2001). We adapted this approach and concept of "block" to the study of discontinuous hard-rock aquifer. Thus, the blocks become spaces or volumes delimited by rock lineaments (at least hectometric and tectonic origin); open or closed that would have a conductive or watertight function, or a capacitive role. This new approach allows moving from the lineament (unique lineament) approach to a surface or volume (including several lineaments) in the study of groundwater flow. 


\section{Study area}

Geographical, economical and climatic characteristics : The study area covering $4000 \mathrm{~km}^{2}$ is located in South-west of the Côte d'lvoire and is part of a part of the watershed of Sassandra River (fig.1).Its climate is a subequatorial (hot and humid) with dense rain forest where agriculture especially cacao plant is the main activity. The extensive use of the land for agriculture induces forest destruction and deep reduction of the biodiversity. The region is a vast peneplain slightly undulating with $200 \mathrm{~m}$ mean altitude, and bowed toward the sea in the South with an average slope of $2 \%$. The drainage system is very dense with the main street Sassandra River (650 km) and a mean annual discharge of $350 \mathrm{~m}^{3} \cdot \mathrm{s}^{-1}$ (Yao, 2009).

Geological and hydrogeological context : Most of the geological formations constitutive of the study area differentiated from the Earth mantle between about 2500 and 1600 M.y. So, the study area belongs to the main supracrustal sequences of Birimian (Papon and Lemarchand, 1973). Moreover, the map presented in figure 2 is a modified copy of the works of these authors.
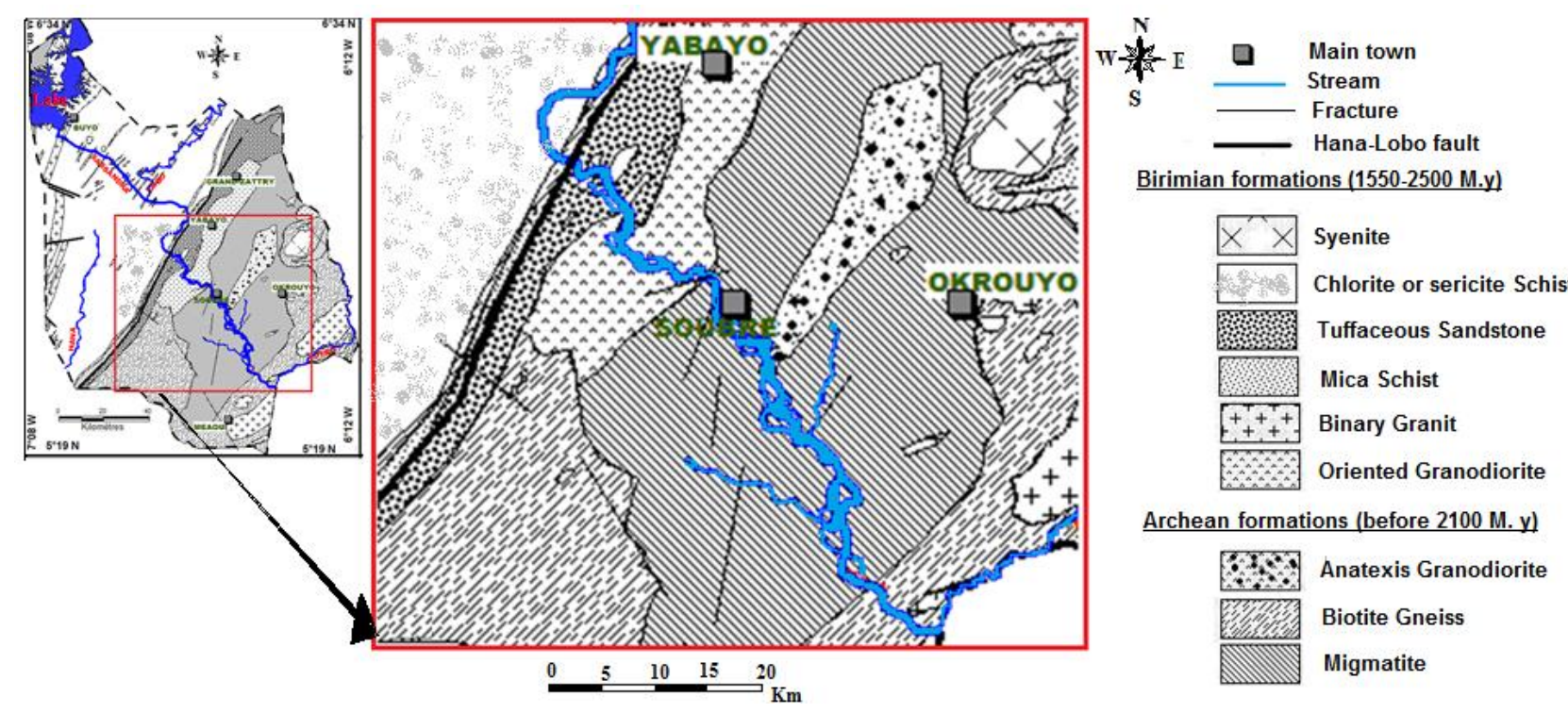

Fig 2. Simplified geological overview (in Papon and Lemarchanad, 1973)

At the south of the Hana-Lobo fault, outcropping rocks associate varied intrusive granitoïd lithologies of the Eburnean orogeny with reworked metamorphosed Archean components. An elongated syntectonic granodioritic body with orthogneiss facies (foliated texture) is associated with the slipping of the crustal fault at early of Eburnean. Between these formations and the Hana-Lobo fault, a tectonic ditch filled with alternated sandstone and volcanic tuff is fringed by a variety of schists more or less sandy (Papon and Lemarchand, 1973). Then, along the southern limit of the region, plutons of binary granite also are parallel to Hana-Lobo fault, but unfoliated. Between those two groups of intrusives rocks and lies a concentric frame of Liberian age looking like an anatexis dome, made of a granodioritic nucleus surrounded by migmatite enclosed within a gneiss ring. This ensemble is scattered with amphibole- pyroxene-rich dykes and the only other expression of a late-Eburnean magmatic phase resides in an isolated, non elongated syenite pluton being intrusive into the gneiss unit.

Brittle Precambrian tectonics and Phanerozoic anorogenic events renewed movement along the joint networks on all scale (Biémi et al., 1991). Deformation phases that superposed during such a long period are difficult to interpret from a tectonic point of view but they resulted in clear fault zones that are quite easily seen from satellite and allow for lineament mapping.

The hard-rock aquifers, which are important for water supply lie within the weathered and fissured/ fractured layers of the crystalline rock (Dewandel et al. 2006). Until quite recently, the hydraulic conductivity of hard-rock aquifers was commonly 
considered as derived either from "tectonic fractures" (late fracturing or fracturing occurring before the weathering process) or from "lithostatic decompression" (Wright 1992; Taylor and Howard 2000). In recent research, relationships between rockweathering processes (and the corresponding weathering profiles) and the hydrodynamic properties of hard-rock aquifers have been progressively resolved (Taylor and Howard, 2000; Lachassagne et al., 2001; Maréchal et al., 2004; Dewandel et al., 2006).

According to Wyns et al. (2004) a typical hard-rock weathering profile is layered, with each layer having its specific hydrodynamic properties; the result is a composite stratiform aquifer. From the top down, we encounter:

- weathering profile layers (laterite and saprolite); because of its clayey-sandy composition, where saturated, the saprolite layer mainly contributes to storage in the overall composite aquifer (Faillat and Blavoux, 1989);

- fissured layer: which is generally characterized by a dense horizontal fissuring in the first few meters and a downwarddecreasing density of subhorizontal and subvertical fissures (Marechal et al. 2004; Wyns et al. 2004; Dewandel et al. 2006);

- fresh basement is permeable only locally, where deeper discontinuities are present. At catchment scale, and for water resource applications, fresh basement can be considered as impermeable and as having a very low storativity (Marechal et al. 2004).

\section{Data and methods}

Datasets: The database used for the study included satellite remotely sensed data imagery, a borehole data and base map (topography and geologic). The remote sensing data were essentially Landsat ETM+ image 7 imagery with $30 \mathrm{~m}$ resolution ensued from the scene 197-56 of 08/02/2001 and a radar image (Radarsat-1) with $50 \mathrm{~m}$ resolution acquired in January 2001. We used Boreholes data collected at Hydraulic regional direction of San Pedro. Most of the database provided information on $\mathrm{X}, \mathrm{Y}, \mathrm{Z}$, depth to the piezometric level after drilling, and the "instantaneous" discharge (i.e., air lift yield measured at the end of the drilling).We used also topographic map of Soubré region and the one of the Southwest geological of Ivory Coast respectively at the scale of $1 / 200000$ and $1 / 500000$.

\section{Methods}

The image processing for mapping lineaments was done by using the software ENVI (environment for visualizing image). All the procedures of processing, combination, and data extraction from these images are illustrated in figure 3 . All the linear man-made structures (streets, forests boundaries, farmland, electrical lines, etc.) were removed from the obtained lineament map. The geological and structural lineaments identified during previous work mapping (Papon and Lemarchand, 1973; Rompel et al., 1988; Biemi, 1992), based on aerial photographs and field observations were found in our network of lineaments. This ability of the method, based on the interpretation of satellite images to find actual fractures already known, not only among the largest, validates our extraction method. This validation led us then extrapolating to give a structural value to all of our lineaments and move the use of the term lineament that of "fracture". Their number is certainly not exhaustive but it reflects the structural frame of the study area. Fracturation map obtained was used as basic for the image analysis that allowed discretizing the fractures field in individualized blocks. The discretization was done by applying VISILOG 4.0 software made by Noesis in 2001 (www.noesisvision.com). The following operations were necessary to individualize the blocks. Graphic display (1) of image file followed by binarization of image (2) by "thresholding" of original image in grayscale and skeletonization by reducing the thickness of lineaments to a pixel. It allows separating compact objects of those with elongated morphology. Afertwards, we proceed to the extraction (4) of extreme points of the skeletons, followed by dilation of points obtained. The dilation of a binary image is to give the value 1 to all pixels which have at least one neighbor of level. Then the Pruning (5) is to remove undesirable ramifications left by skeletonization. We pass by after to reconstruction (6) of basic networks and impasses followed by removal (7) of isolated segments. Labeling (8) to identify each segment and perform individual measurements. A label is an indexing and identification of all particles (segments or geometric sharpe) in the image. Quantization is applied to each particle and for the area, perimeter, Feret diameters (projections along the axes of grid), elongation, orientation etc. We end by removing (9) of the blocks 
connected to contours and final labeling to realize individual measures on all blocks in the binary image.

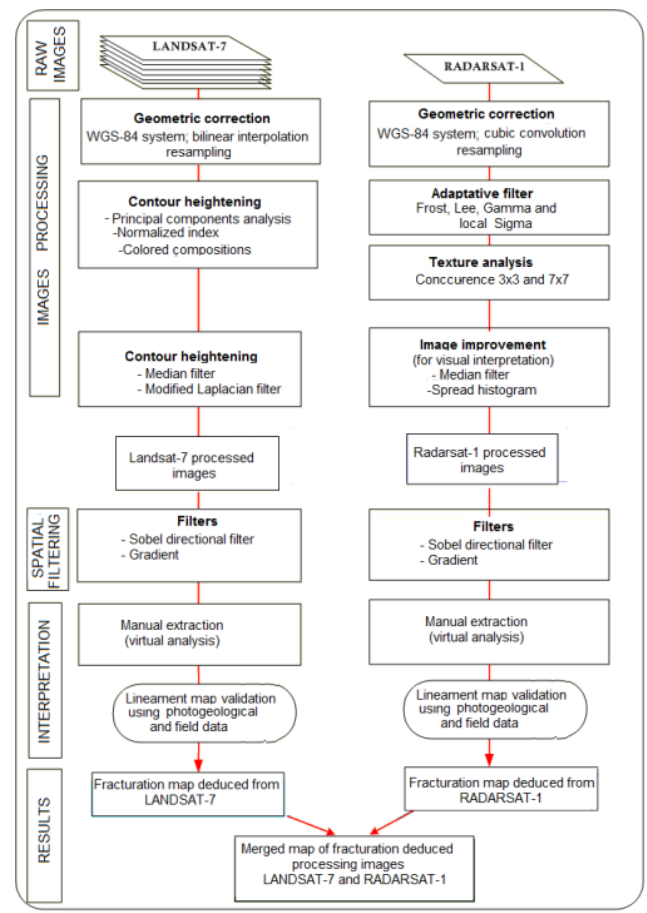

Fig 3. Method of lineament extraction from satellite images

The new parameters, representative of block are orientation of long axis and equivalent diameter (corresponding to a virtual circle diameter which is equivalent to surface of considered block). Fracturation analyse through mathematical morphology allowed getting quantitative information (surface, equivalent diameter) of the aquifers blocks that juxtapose themselves in the study area. The obtained data constituted the basis of the statistical analysis of the blocks. The shape of empiric distribution of lengths (segment, equivalent diameter) was adjusted in accordance with chi2 and Kolmogorov-Smirnov (K-S) test. The distribution was compared to theoretical models of exponential, lognormal, gamma and power distributions.

\section{RESULTS}

Morpho-structural alignment field: lineaments: The morpho-structural alignment field (figure 4) obtained by satellite images processing shows 983 lineaments having variable sizes. Statistical analyse of these fracture traces showed some lengths ranging from $0.319 \mathrm{~km}$ to $48.534 \mathrm{~km}$ with a mean of $5.633 \mathrm{~km}$. Also, $58 \%$ of the lineaments have some lengths inferior to $5 \mathrm{~km}$ while $96 \%$ shows 1a length below $5 \mathrm{~km}$. The rose chart (figure 5) allowed distinguishing the different families of lineaments with a significant variation among the orientations. The N60-N100 (majority), N100-N140, and the vertical fractures or subvertical (N0-N20 and N170-N180) represent the three main families. The fractures with N20-N60 and N140-N170 orientations are ultra minority (frequency inferior to $5 \%$ ). They express a background noisy that results not only to the variability of the significant classes of family, but also geological contacts that had been confused to some fractures and hydrogaphy. Both first class of family regroup the majority of data in an only one family centered on N80-N90 that remains the predominant family with a frequency above $10 \%$. 
Am. J. Sci. Ind. Res., 2012, 3(4): 208-220

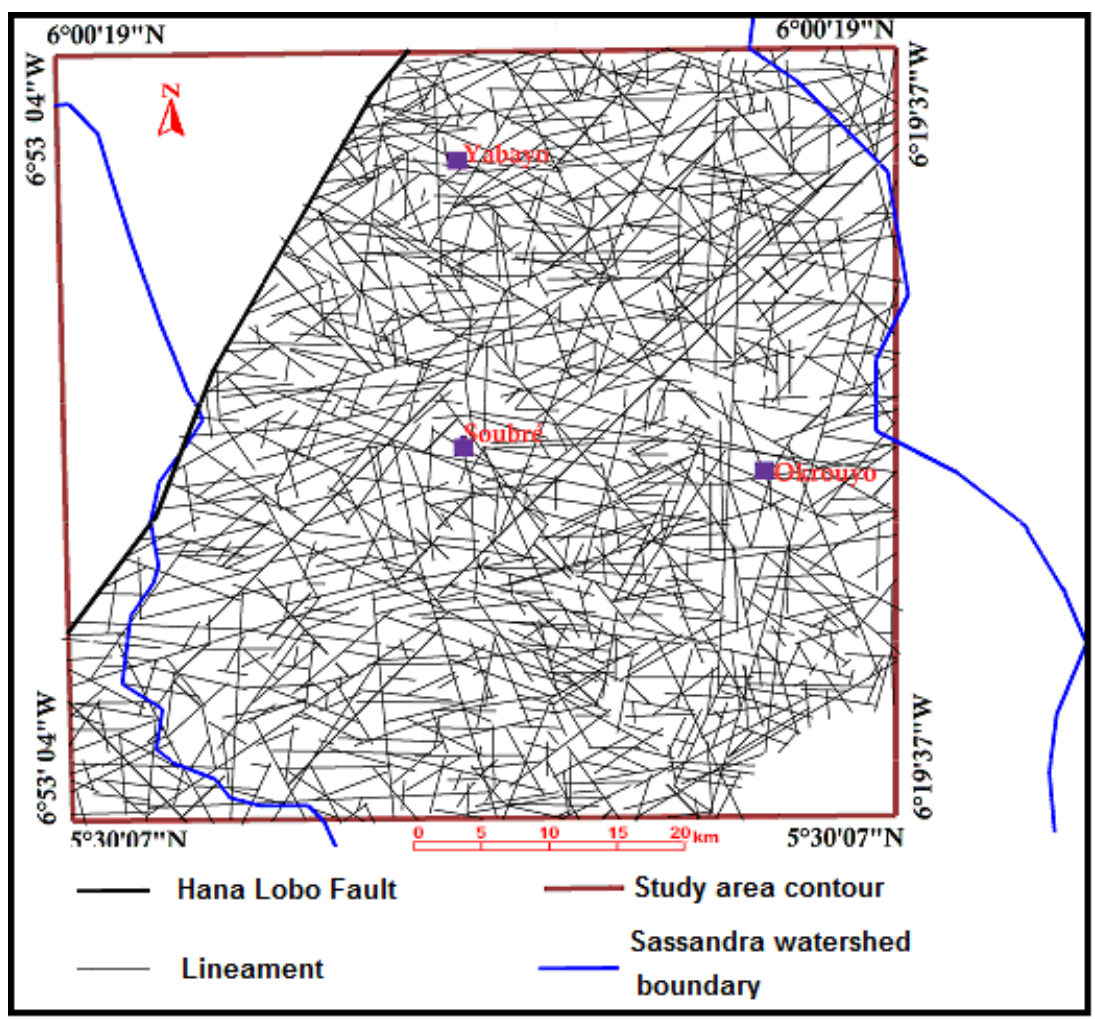

Fig 4. Lineament deduced from satellite imagery processing

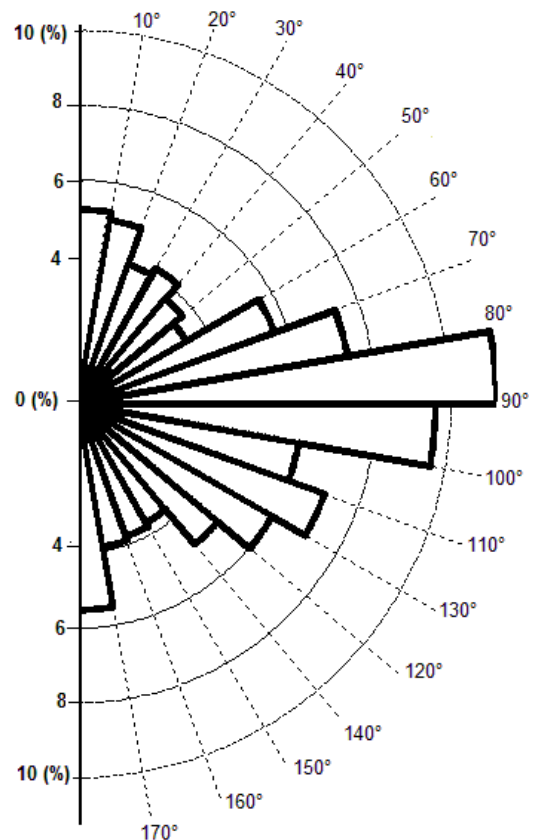

Fig 5. Rose diagram representing orientations of lineaments 
Am. J. Sci. Ind. Res., 2012, 3(4): 208-220

From lineaments to individualized blocks: Figures 6 and 7 present the result of the fracturation map (figure 4) analyse procedure. Analysis of the map of lineaments followed by its "labeling" portray information such as segment length; perimeter, block area, the equivalent diameter, and grand axis block orientation. The table I summarizes the numerical values of these parameters. Figure 6 depicts the individualized and isolated segments. Each segment is graphically recognizable by its color which is different from its closest one. Thus, there are 4296 segments whose lengths varying $0.042 \mathrm{~km}$ to $5.4 \mathrm{~km}$ with a mean of $1 \mathrm{~km}$. The gap between the mean and the standard deviation justifies the large dispersion between the segments length.

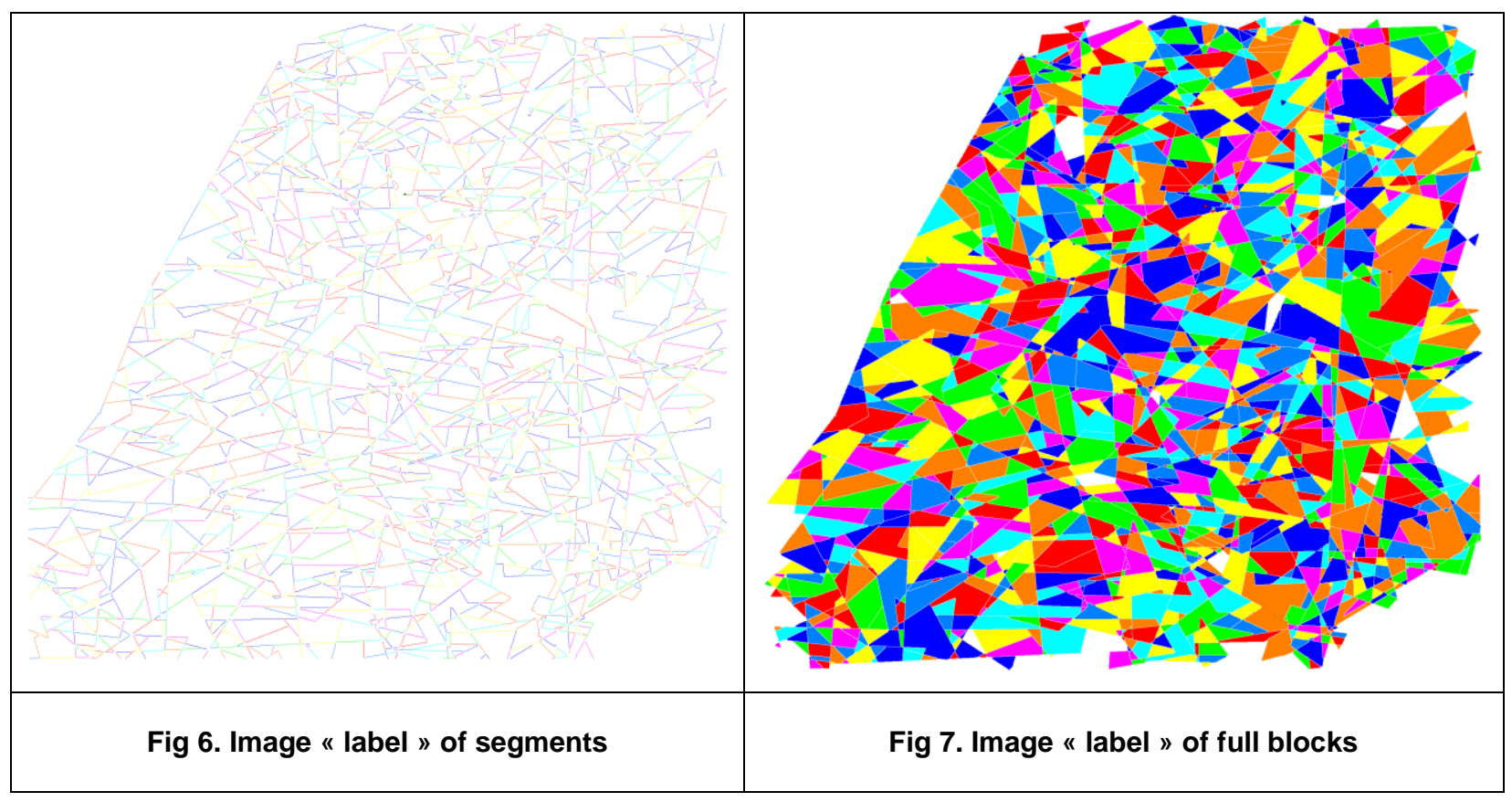


Table I. Summary of the blocks parameters results

\begin{tabular}{|l|c|c|c|c|c|}
\hline & $\mathbf{L}_{\mathbf{s}}(\mathbf{k m})$ & $\mathbf{D}_{\mathbf{e}}(\mathbf{k m})$ & $\boldsymbol{\theta}\left(^{\circ}\right)$ & $\mathbf{P}_{\mathbf{b}} \mathbf{( k m )}$ & $\mathbf{S}_{\mathbf{b}}\left(\mathbf{k m}^{\mathbf{2}}\right)$ \\
\hline $\mathbf{T}$ & 0.04 & 0.12 & 0.00 & 0.36 & 0.01 \\
\hline $\mathbf{T}$ & 5.42 & 5.34 & 162.00 & 38.57 & 22.41 \\
\hline $\boldsymbol{\mu}$ & 1.01 & 1.05 & 75.84 & 5.15 & 1.29 \\
\hline $\boldsymbol{\sigma}$ & 0.72 & 0.74 & 58.38 & 3.99 & 1.93 \\
\hline $\boldsymbol{\eta}$ & 0.47 & 0.19 & 18.00 & 2.99 & 0.03 \\
\hline
\end{tabular}

Mean $(\mu)$. Standard deviation $(\sigma)$. Minimum $(\mathrm{T})$. Maximum $(\mathrm{T})$. Model $(\eta)$. block orientation bloc $(\theta)$ Block perimeter $(\mathrm{Pb})$. Block surface $\left(\mathrm{S}_{\mathrm{b}}\right)$ Segment length $\left(\mathrm{L}_{s}\right)$. Equivalent diameter $\left(D_{e}\right)$. Bloc perimeter $\left(P_{b}\right)$.

Along the lengths of the individualized segments, the result of the adjustments according to chi2 (X2) and Kolmogorov-Smirnov (K-S) tests shows that the calculated values using chi2 test are clearly superior to the theoric ones. According to this test, the lognormal, gamma, and exponential law do not allow to describe statistically this parameter at the significance threshold of $1 \%$. However, these tests show that the best law remains the log-normal distribution with the distance of Kolmogorov is the smallest (table II). Indeed, more the distance of K-S is small, better is the adjustment to the distribution in question.

Table II. Adjustment test of the segment length (block side)

\begin{tabular}{|c|c|c|c|c|}
\hline \multirow{2}{*}{$\begin{array}{c}\text { Distribution } \\
\text { law }\end{array}$} & $\begin{array}{c}\boldsymbol{\chi}^{2} \\
\text { Observed }\end{array}$ & $\begin{array}{c}\text { Degree } \\
\text { of } \\
\text { freedom }\end{array}$ & $\begin{array}{c}\text { Expected } \\
\boldsymbol{\chi}^{2}\end{array}$ & $\begin{array}{c}\text { K-S } \\
\text { test }\end{array}$ \\
& $(\alpha=1 \%)$ & $\begin{array}{c}\mathrm{p} \\
<0.01\end{array}$ \\
\hline $\begin{array}{c}\text { Lognormal }(\mu=- \\
0.21 ; \alpha=0.68)\end{array}$ & 96.36 & 9 & 21.66 & 0.038 \\
\hline $\begin{array}{c}\text { Gamma } \\
(\varepsilon=0.43 ;=2.37)\end{array}$ & 104.27 & 6 & 16.81 & 0.064 \\
\hline $\begin{array}{c}\text { Exponential } \\
(\lambda=0.99)\end{array}$ & 510.98 & 10 & 23.20 & 0.203 \\
\hline
\end{tabular}

Mean $(\mu)$. Standard deviation $(\sigma)$. Scale parameter $(\varepsilon)$. Shape parameter $(\beta)$. Exponential parameter $(\lambda)$

The adjustment of this parameter according to the power law doesn't give convincing results. Only the 0.378-2.64 km interval should obey a power law expressing as follows:

$\mathrm{n}(\mathrm{I})=16.59 \times \mathrm{I}^{-2.99} \quad\left(\mathrm{R}^{2}=0.91\right)$

With this low coefficient of determination and short interval, such law cannot be considered as probable.

Values of equivalent diameter of the blocks have been adjusted by the same models as well as the length of the segments. The khi2 and Kolmogorov-
Smirnov tests at the significance threshold of $1 \%$ led to accept the gamma law (table III).

Table III. Adjustment test of the block equivalent diameter length

\begin{tabular}{|l|l|l|l|l|}
\hline Distribution law & $\begin{array}{l}X^{2} \\
\text { Observed }\end{array}$ & $\begin{array}{l}\text { Degree } \\
\text { of } \\
\text { freedom }\end{array}$ & $\begin{array}{l}\text { Expected } \\
x^{2}\end{array}$ & $\begin{array}{l}\text { K-S } \\
\text { test } \\
\text { p } \\
<0.01\end{array}$ \\
\cline { 4 - 5 } & & & & \\
\hline $\begin{array}{l}\text { Lognormal } \%) \\
0.20 ; \alpha=0.74)\end{array}$ & 51.17 & 8 & 20.09 & 0.045 \\
\hline $\begin{array}{l}\text { Gamma }(\varepsilon=0.48 ; \\
=2.51)\end{array}$ & 13.91 & 6 & 16.81 & 0.029 \\
\hline $\begin{array}{l}\text { Exponential } \\
(\lambda=0.95)\end{array}$ & 218.98 & 10 & 23.20 & 1.139 \\
\hline
\end{tabular}

Mean $(\mu)$. Standard deviation $(\sigma)$. Scale parameter $(\varepsilon)$. Shape parameter ( $\beta$ ). Exponential parameter $(\lambda)$

For comparison purpose, the equivalent diameter of the block has also been submitted to the power law. It reveals that in the interval ranging from $0.690 \mathrm{~km}$ to $2.61 \mathrm{~km}$, the points are aligned following a straight line. The profile is assumed to be a power law expressed as follows:

$n(d)=26.11 \times d^{-3.75} \quad\left(R^{2}=0.90\right)$.

Once again the coefficient $R^{2}$ and extend of the interval are not significant. The adjustment to power law of this variable is mediocre. The characteristic exponent presents a high value widely superior to 3 . That means the passage from the segments to the blocks has again increased the proportion of the small objects.

In fact, these segments are the sides of geometric figures presented in figure 7 . These polygons bring out the 1869 individualized aquifer blocks. These blocks, in our view are discontinued aquifers differentiated by major lineament. The block surface varies between $0.011 \mathrm{~km}^{2}$ and $22.400 \mathrm{~km}^{2}$ and it will be substituted by the equivalent diameter. The diameters of the blocks range from $0.121 \mathrm{~km}$ to 5.341 $\mathrm{km}$ with a mean of $1.050 \mathrm{~km}$.

The directional distribution of the equivalent diameters (figure 8) gets organized around a peak toward N20 and a minimum at N100. The blocks of $\mathrm{E}-\mathrm{O}$ direction are rare. However, the blocks of N20N50 orientation are the most frequent (highest 33\%). A second peak is notable between N160 and N170. 


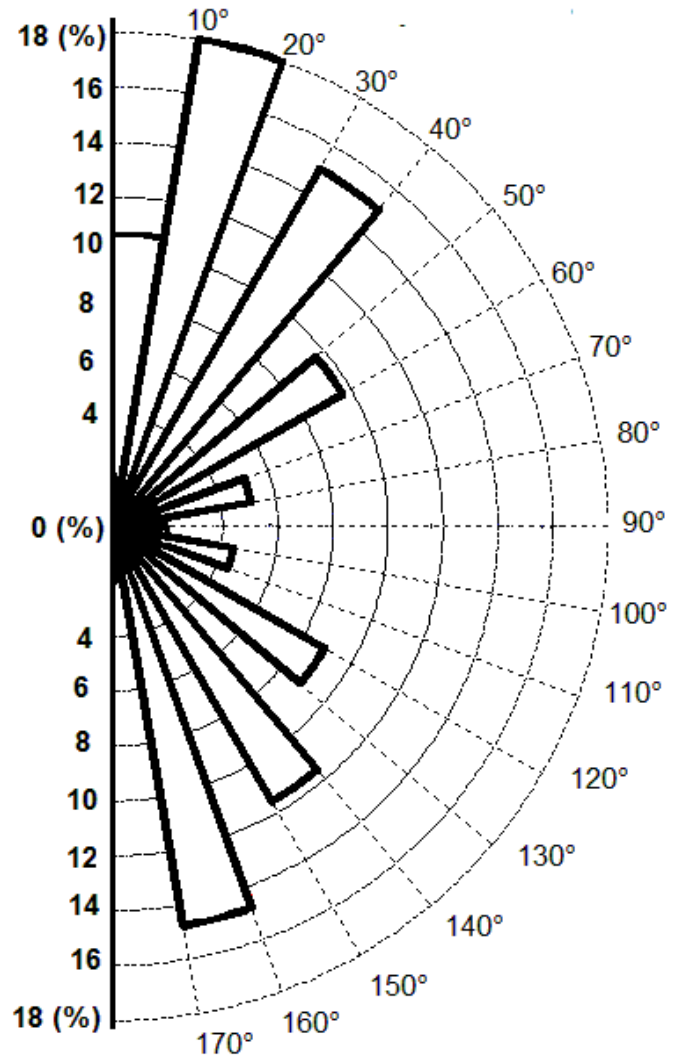

Fig 8. Directional rosette of the block's long axis

In comparison with the lineaments, directions of the equivalent diameter are more marked and significant. Indeed, three significant directions (N20, N40, and $\mathrm{N} 170$ ) with frequencies superior to more than $14 \%$ are observed whereas N40 which is the direction of birimian formation appears in the orientation of blocks long axes.

Flow and block's surface: Figure 9 portrays the correlation between the flow (observed in during pumping tests) of 84 wells distributed throughout the study area and the block's size. Depending on the position of the points in the graph, we sought to find an affinity relationship between surface of the block and the flow rate of boreholes. Overall, there is an inverse relationship between flow and block's surface However, arrangement of points in the graph does not trace a single trend line. So we divided the items into four groups which present the determination coefficient superior to 0.9 . Group $\mathrm{N}^{\circ} 4$ is the set of points that line up in the form of a decreasing exponential envelope curve clearly corroborates the inverse relationship between the surface and flow.

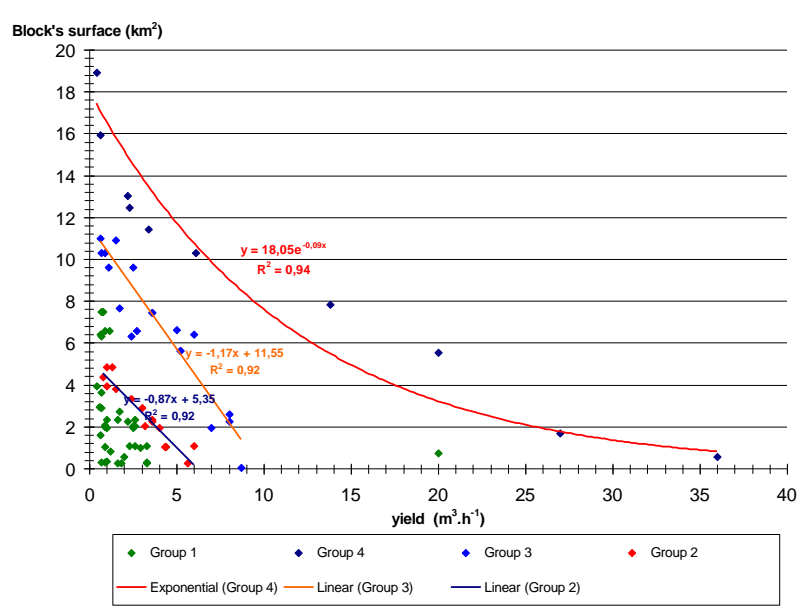

Fig 9. Relationship between well yield and block surface

We have also observed that, distances between the well and the closest lineament is checked for the other points of the curb. Table IV shows that the different distances do not exceed $2.5 \mathrm{~km}$ and the surface of block is not correlated with distance from a closest lineament.

Table IV. yields, block surface and distance in accordance with the closest lineament

\begin{tabular}{|l|l|l|l|l|}
\hline Locality & Code & $\begin{array}{l}\text { Well yield } \\
\left(\mathbf{m}^{3} \cdot \mathbf{h}^{-\mathbf{1}}\right)\end{array}$ & $\begin{array}{l}\mathbf{S} \\
\left(\mathbf{k m}^{2}\right)\end{array}$ & $\begin{array}{l}\mathbf{D} \\
\mathbf{( k m})\end{array}$ \\
\hline SIPEF-CI & M7 & 0.40 & 18.93 & 2.493 \\
\hline TAYO & & 0.6 & 15.93 & 0.5 \\
\hline KPADA & M9 & 2.2 & 13.01 & 0.9822 \\
\hline KOZIAYO & K2 & 2.3 & 12.46 & 1.549 \\
\hline BABAYEROUA & & 3.4 & 11.45 & 1.354 \\
\hline GALEA & & 6.1 & 10.29 & 1.734 \\
\hline BAKAYO & M1 & 13.8 & 7.855 & 2.3 \\
\hline KOPERAGUI & L24 & 20.00 & 5.56 & 0.3266 \\
\hline KOFFIKRO & & 27 & 1.688 & 0.26 \\
\hline KOUAMEKRO & & 36 & 0.556 & 1.081 \\
\hline
\end{tabular}

Yield = yield at the end of the drilling; $S=$ surface of the aquifer block containing the well surface du bloc;

$D=$ the smallest distance between the well and the closest lineament.

The groups 2 and 3 follow each a decreasing linear curve whose characteristics are shown in figure 8 . The same trend is repeated more the surface of the 
block is large, the lower the volume of water pumped. However, there are also some small blocks that have insignificant flows.

\section{DISCUSSION}

The set of mapping lineamentary techniques allowed highlighting an important part of the lineaments existing in the study zone (a part of Sassandra watershed). Despite the sampling distortion inherent with the use of satellite imagery in hydrogeology (Sander, 2007), these lineaments have been regarded as fractures crossing the study zone. The fundamental difficulty in discussing lineaments reflects the complex processes of lineament interpretation and the associated bias effects.

Many previous authors have been considering that lineaments extracted from remote sensing data indicated fractures in the Earth's crust. For instance, Kaneko (1967) stated that about 60 to $70 \%$ of lineaments interpreted on aerial photographs correspond to fractures. Some authors inferred that only major lineaments reflected crustal structures (Lattman, 1958; Matsuno, 1968).

The lineaments identified in this study have got varied extensions with a very important proportion of lineaments less than $15 \mathrm{~km}$. Also, they have been compared to published geologic maps. It appears from this geological review that most of the lineaments in the Côte d'Ivoire and particularly in the southwest are the same to lineaments extracted from remote sensing data. So, they can be considered as fracture sets.

The statistical parameters analyse show that the fractures follow a log-normal law while the spacing (between lineaments) follows an exponential law or gamma practically exponential (Yao, 2009). These results are consistent with the conclusions from many works about the fracturation at any scale (Darcel, 2002; Fouche, 1999). However, the studies made respectively by Odling (1997), Bour (1997), Lasm et Razack (2001), Kouamé et al, (2010) undertaken the idea that the fractures lengths are distributed according to the power law. This shows the difficulty to model the distribution of the lineaments.

The discretization approach aquifers block proposed by our study can no longer focus only on major lineaments but on the rock volume delimited by them. They are more or less isolated aquifers that may contain several lineaments not mapped due to the resolution of the images. The study of block's switches the regional level (through the major lineaments) to a local approach (size of a city).

The notion of "block" is a new approach in the study of discontinuous aquifer. The geometric characteristics of blocks (segment length, area and orientation) provide information on the probability that a certain configuration occurs in the study area, such as the occurrence of small blocks. The data emanating from the network approach by the notion of the block complete the most classical information about the lengths number of class-directional lineaments.

In statistical analyse, neither length of lineaments, nor the length of the segments or the diameter of the blocks obey the power law, however it is more and more applied to study of the geological objects (De Dreuzy, 2000, Bodin and Razack, 1999, Youan Ta et al., 2008). The low linear coefficient of determination ( $R 2 \approx 0.9$ ) and the lengths and diameters of block segments (sides of blocks) are all of the same order, they cannot be deemed acceptable for a modeling. An auto-similarity in the principal variable of the network is not therefore to be considered. The characterization of a fractal behavior would involve a change of the resolution imagery, consequently the usage of aerial photography.

The transition to the segments towards lineaments and segments into shows an increasing slope (exponent of the power law).

This clear increase from 2.37 to 2.99 then to 3.75 reflects that we deal with objects whose degree of connectivity is growing. Indeed, the linear fitted to a power law distribution proves to be a good indicator of the connectivity of the object (block). In addition, lack of self-similarity implies that the study of discontinuous aquifers should be conducted locally (i.e. within a small surface like the block) and not only at a regional scale as in the case of lineaments identified on satellite images.

The study of discontinuous aquifers cannot be extrapolated to the regional scale without any power law. This failure in modeling monofractal fully justifies our approach by disaggregating the watershed area into local blocks. This observation is corroborated by the correlation between the flow of borehole and the block's surface.

The High flow rates observed in small block show that the major lineaments are not always responsible for the outflow of groundwater. They isolate discontinuous aquifers where the fracture density 
(fissured horizon) and geomorphology have a role in the circulation of groundwater (Lachassagne et al., 2001, Maréchal et al., 2004).

Thus, lineaments mapped at small scale (regional scale) cannot be appropriate to study groundwater flow in hard-rock area. The "small" fracturation (nhectometer to n-kilometer) existing inside each block contributes probably to the internal circulation. However, the scale of observation at which we worked, this fracture is unknown or biased. According to Yao et al. (2012), this bias is estimated in the department of Soubré to $17 \%$.

Rather, it must be local because they are small fractures present in the fissured horizon which largely control groundwater flow in crystalline and metamorphic bedrocks. Where, the rationale for the approach proposed by our study block.

The probability to find some blocks according to N20 direction is very strong, and the other directions are symmetrical to this peak. That is therefore the privileged orientation of groundwater flow in this part of Sassandra watershed. This observation can be spread at least over the whole granitoid unite of the department. But, if the scale of study is unknown or distorted we cannot define with certainty the preferred orientation of the sub-network of fractures and flow within a block. However, based on the study of Faillat (1986) and non-fractal property, we can expect that subnetwork does not direct differently the anisotropy of the aquifer and consequently, it would not change the overall direction of groundwater drainage.

However, this flow depends on the capacity of fractures that have differentiated this block to drain the water or soil overlying formations to pass through it by infiltration water. The quantity of stored water into a block is strongly related to soil's permability.

Conclusion: Lineaments of Sassandra watershed located in the department of Soubre have been mapped by following an appropriate methodology used in several studies. Correlation of these lineaments with the geological structures allowed assimilating as fractures going through the study zone. The fracture field has been discretized into blocks (mesh network of fissures). These ones formed the discontinued aquifer that could be counted in the study area. They are mostly guided accordingly N20 direction. The adjustment of the equivalent diameter to the power law as well as the segments and lineaments allowed bringing out that the usability degree of the blocks is the best in comparison with the lineaments. Thus, they became the best components for the study of the hydrodynamism in a confined space (local) in hardrock. Overall, the maximum flow expected from well is important in the small blocks, justifying therefore the predominant role that plays the fracturation density in the hard-rock under flow.

\section{REFERENCES}

Berkowitz, B (1995). Analysis of fracture connectivity using percolation theory. Math. Geol. 27 : 467-483.

Biémi, J (1992). Contribution à l'étude géologique, hydrogéologique et par télédétection des bassins versants sub-sahéliens du socle précambrien d'Afrique de l'Ouest: hydrostructurale, hydrodynamique, hydrochimie et isotopie des aquifères discontinus de sillons et aires granitiques de la Haute Marahoué (Côte d' Ivoire). Thèse de doctorat ès Sciences Naturelles, Université d'Abidjan, 480 p.

Biémi J., Gwyn Q.H.J., Deslandes S et Jourda, P (1991). Géologie et réseaux de linéaments régionaux du bassin versant de la Marahoué, Côte d'Ivoire: cartographie à l'aide des données Landsat TM et du champ magnétique total. In : Gagnon, P. (Ed.), Télédétection et gestion des ressources. Association québécoise de télédétection. 692 VII, pp 135-145

Biemi, J., Jourda, JP., Deslands, S et Gwyn, H (1997). Positionnement, productivité et gestion des forages en milieu fissuré de Côte d'Ivoire par télédétection et système d'information géographique. Actes de l'Atelier international sur la télédétection et gestion des ressources en eau, 1997. Ed. FAO, Rome, pp 245268.

Bodin, J et Razack, M (1999). L'analyse d'images appliquée au traitement automatique de champ de fractures. Propriétés géométriques et lois d'échelles. Bulletin de la société géologique de France, tome 170, $\mathrm{n}^{\circ} 4$, pp 579-593.

Bour, O (1997). Transfert de fluide dans les milieux fracturés : effets d'échelle. Thèse de doctorat, Université de Rennes 1, 200 p.

Courtois, N, Lachassagne, P., Wyns, R., Blanchin, R., Bougaïré, D.F., Somé, S and Tapsoba, A (2010). Large-Scale Mapping of Hard-Rock Aquifer Properties Applied to Burkina Faso. Ground Water. 48(2) : 269283.

Darcel, C (2002). Corrélation dans les réseaux de fractures: caractérisation et conséquences sur les propriétés hydrauliques. Thèse de doctorat, Université de Rennes 1, France, 223 p.

De Dreuzy, JR (2000). Analyse des propriétés hydrauliques des réseaux de fractures. Université de Rennes 1, France, $101 \mathrm{p}$.

Dewandel, B., Lachassagne, P., Wyns, R., Marechal, J-C and Krishnamurthy, NS (2006). A generalized 3-D geological and hydrogeological conceptual model of 
granite aquifers controlled by single or multiphase weathering. Journal of Hydrology. 330 : 260-284.

Engalenc, M (1979). Méthode d'étude et de recherche de l'eau souterraine des roches cristallines de l'Afrique de I'Ouest. Géohydraulique CIEH. Vol. II, 194 p.

Empereur-Mot, L (2001). La fragmentation naturelle des massifs rocheux. Modèle de blocs et de bases de données tridimensionnelles. In: Géol. Alpine, mémoire, HS n`35, Université de Grenoble.

Faillat, J-P (1986). Aquifères fissurés en zone tropicale humide: structure hydrodynamique et hydrochimie. Thèse d'état, Université de Montpellier, 536 p.

Faillat, J.-P et Blavoux B (1989). Caractères hydrochimiques des nappes des roches endogènes en zone tropicale humide : l'exemple de la Côte d'Ivoire. J. of Africa Earth Sciences. 9(1) : 31-40.

Fouché, O (1999). Caractérisation géologique et géométrique, et modélisation $3 \mathrm{D}$, des réseaux de discontinuités d'un massif granitique reconnu par forages carottés, massif de Charroux-Civray (Vienne, France). Thèse de doctorat en géologie de l'ingénieur. ENPC-ENSMP, 296 p.

Hobbs, W.H (1904). Lineaments of the Atlantic border regions Géol. Soc. Amer. Bull. 15: 483-506.

Jourda, JP, Saley, B.M., Kouamé, K, Kouadio, B.H, Biémi, $J$ et Razack, M (2005). Gestion et protection des ressources en eaux souterraines : contribution d'un SIG à la réalisation de la carte de vulnérabilité à la pollution des aquifères fissures de Korhogo (Nord de la Côte d'Ivoire) selon la méthode DRASTIC. Conférence Francophone ERSI. 5 et 6 octobre 2005, Issy-les-moulineaux. France

http://www.esrifrance.fr/sig2005/communications2005/jourd a/jourda.htm consulté en octobre 2011.

Jourda, JP., Djagoua, E.V., Kouamé, K., Saley, B.M., Gronayes, C., Achy, J-J et Razack, M (2006). Identification et cartographie des unités lithologiques et des accidents structuraux majeurs du département de Korhogo (Nord de la Côte d'Ivoire): Apport de l'imagerie ETM+ de Landsat. Télédétection. 6(2) : 123142.

Kaneko, S (1967). Structural geography. Kokin-Shoin, Tokyo, p 192.

Kouame, KF., Akaffou A., Lasm T., De Dreuzy JR., Davy, P., Bour, O (2005). Simulation des écoulements dans les réservoirs fracturés : application au socle Archéen de Touba (Nord-Ouest de la Côte d'Ivoire). Actes du Colloque Internationale SITIS 05, 2005. Yaoundé (Cameroun), 27 Nov.-1er Déc. 2005: 39-46.

Kouame, KF., Lasm T., De Dreuzy JR., Akaffou A., Davy, P and Bour, $O$ (2010). Contribution d'un modèle hydrogéologique à fractures discrètes à l'étude des aquifères fracturés du socle Archéen de Touba (NordOuest, Côte d'Ivoire). Revue des sciences de l'eau. 23(1) : 41-56.
Lachassagne, P., Wyns, R., Bérard, P., Bruel, T., Chéry, L., Coutand, T., Desprats, J.-F and Le Strat, P (2001). Exploitation of high-yield in hard-rock aquifers: Downscaling methodology combining GIS and multicriteria analysis to delineate field prospecting zones. Ground Water. 39(4): 568-581.

Lasm, T and Razack, M (2001). Scaling laws in crystalline hard rock fracturing and in the associated river network. C.R. A.S., Séries IIA - Earth and Planetary Science. 333(4): 225-232.

Lattman, L.H (1958). Techniques of mapping geologic fracture trace and lineaments on aerial photographs. Photogram. Eng. 24: 568-576.

Lattman, L.H and Parizek, R.R (1964). Relationship between fracture traces and the occurrence of groundwater in carbonate rocks. Journal of Hydrology. 2: 73-91.

Mabee, S.B., Hardcastle, K.C and Wise, D.U (1994). Amethod of collecting and analyzing lineaments for regional-scale fractured-bedrock aquifer studies. Ground Water. 32(6): 884-894.

Mabee, S.B., Curry P.J and Hardcastle K.C (2002). Correlation of lineaments to ground Water Inflows in a Bedrock Tunnel. Ground Water. 40(1): 37-43.

Magowe, M and Carr, J.R (1999). Relationship between lineaments and ground water occurrence in western Botswana. Ground Water. 37(2): 282-286.

Maréchal, J-C, Dewandel B and Subrahmanyam, K (2004). Contribution of hydraulic tests at different scales characterize fracture network properties in the weathered-fissured layer of hard rock aquifers. Water Ressources Research. 40: 11-17.

Matsuno, K (1968). Interpretation of geologic structures on aerial photographs. How to treat linear visible on aerial photographs. Chinetsu, 17: 14-21.

Odling, NE (1997). Scaling and connectivity of joint systems in sandstone from western Norway. Journal of Struct. Geol. 19(10) : 1257-1271.

Papon, A et Lemarcharnd, R (1973). Géologie et minéralisation du sud-ouest de la Côte d'Ivoire. Synthèse des travaux de l'opération SASCA (19621968). SODEMI, Abidjan 284 p.

Rompel A.K, Koné A.M., Knupp K.P., Burvenich, Tmjag (1988). Structural interpretation of the Hana-Lobo Concession area, western Ivory Coast. Internal AAC report 15/133/500/98/78, $23 p$

Sander, P (2007). Lineaments in groundwater exploration: a review of applications and limitations. Hydrogeol. J. $15: 71-74$.

Savané, I., Affian, K., Koli, B. Z., Cougny, G (1997). Stratégie de recherche des eaux souterraines dans les régions à substratum cristallin; exemple du département de Korhogo (Côte d'Ivoire). Bull. de l'Association Internationale de Géologie de l'ingénieur. $44: 79-88$. 
Stauffer, D (1987). Introduction to Percolation Theory. Taylor and Francis, London, 124 p.

Tagini, B (1971). Esquisse Structurale de la Côte d'Ivoire. Essai de géotechnique régionale. Thèse d'État, Université de Lausanne, $302 \mathrm{p}$.

Taylor, R and Howard, K (2000). A tectono-geomorphic model of the hydrogeology of deeply weathered crystalline rock: Evidence from Uganda. Hydrogeology Journal. 3(8): 279-294.

Woodruff, C.M., Cepeda, J-C., Gever, C., Henry, C.D., Macperson, G.L and Mcbride, M.W (1982). Geothermal Resource Assessment for the State of Texas. Bureau of Economic Geology, University of Texas, Austin, Texas, $275 \mathrm{p}$.

Wright, E.P (1992). The hydrogeology of crystalline basement aquifers in Africa. In Hydrogeology of crystalline basement aquifers in Africa, ed. E.P. Wright and W.G. Burgess, pp. 1-27. London, UK: Geological Society, Special Publication $n^{\circ} .66$.

Wyns, R., Baltassat, J.-M., Lachassagne, P., Legchenko, A., Vairon J and Mathieu, F (2004). Application of proton magnetic resonance sounding to groundwater reserve mapping in weathered basement rocks (Brittany, France). Bull. Soc.géol. fr. (1): 21-34.

Yacé, I (2002). Initiation à la géologie. L'exemple de la Côte d'Ivoire et de l'Afrique de l'Ouest. Éditions CEDA (Abidjan), Côte d'Ivoire, $183 \mathrm{p}$.

Yao, KT (2009). Hydrodynamisme de l'eau souterraine dans les aquifères de socle cristallin et cristallophyllien du Sud-Ouest de la Côte d'Ivoire : cas du département de Soubré. Apports de la télédétection, de la géomorphologie et de l'hydrogéochimie. Thèse de doct. Conservatoire national des Arts et Métiers, Paris, p. 284.

Yao, KT., Fouché, O., Oga, M-S., Assoma, T.V. (2012). Extraction de linéaments structuraux à partir d'images satellitaires, et estimation des biais induits, en milieu de socle précambrien métamorphisé. Revue Télédétection. 10(4):161-178.

Youan Ta, Lasm, T., Jourda, J-P., Kouamé, KF et Razack, M (2008). Cartographie structurale par imagerie satellitaire ETM+ de Landsat-7 et analyse des réseaux de fractures du socle précambrien de la région de Bondoukou (Nord-Est de la Côte d'lvoire). Télédétection. (2) : 34-42. 